\title{
The Combination of ACE Inhibition plus Sympathetic Denervation Is Superior to ACE Inhibitor Monotherapy in the Rat Renal Ablation Model
}

\author{
Peter Hamar ${ }^{a, c}$ Gabor Kokeny ${ }^{a, c}$ Peter Liptak ${ }^{b, c}$ Jan Krtil c Marcin Adamczak ${ }^{c}$ \\ Kerstin Amann ${ }^{\mathrm{e}}$ Eberhard Ritz ${ }^{c}$ Marie-Luise Gross ${ }^{d}$ \\ a Institute of Pathophysiology, Semmelweis University, Budapest, and ${ }^{b}$ Department of Pathology, University of \\ Szeged, Szeged, Hungary; ' CDepartment of Internal Medicine and d Department of Pathology, University of \\ Heidelberg, Heidelberg, and e Department of Pathology, University of Erlangen-Nürnberg, Erlangen, Germany
}

\section{Key Words}

ACE inhibitor, progression • Renin-angiotensin system •

Remnant kidney model $\cdot$ Sympathetic system

\begin{abstract}
Background: The blood pressure-independent renoprotective actions of the blockade of the renin-angiotensin and the sympathetic nervous system are well documented, but monotherapies fail to completely abrogate progression. We investigated whether combined inhibition of the two systems provides additive renoprotection. Methods: After subtotal nephrectomy (SNX) or sham operation, rats underwent resection of dorsal roots, i.e. rhizotomy or sham rhizotomy. Subsequently, they received tap water or quinapril in drinking water for 16 weeks ( $n=18$ /group). Albuminuria, blood pressure and kidneys were assessed (morphometry, immunohistochemistry). Results: At the end of the study telemetric blood pressure in SNX was $118 \pm 16 \mathrm{~mm} \mathrm{Hg}$, in SNX + rhizotomy $110 \pm 10 \mathrm{~mm} \mathrm{Hg}$, in SNX + quinapril $103 \pm 9 \mathrm{~mm}$ $\mathrm{Hg}$ and in SNX + quinapril + rhizotomy $95 \pm 7 \mathrm{~mm} \mathrm{Hg}$. Albu-
\end{abstract}

P. Hamar, G. Kokeny and P. Liptak contributed equally to this paper. minuria in the respective groups was $169 \pm 75,86 \pm 45,15$ \pm 23 and $5 \pm 4 \mathrm{mg} / 24 \mathrm{~h}$. The glomerulosclerosis index was $1.40 \pm 0.6,0.80 \pm 0.23,0.37 \pm 0.16$ and $0.31 \pm 0.15(p<$ 0.001 ). Only combined intervention caused significant reduction of the glomerular volume and podocyte hypertrophy. The lowest indices for nitrotyrosine, NOS-1 (nNOS), TGF- $\beta$ and interstitial collagen were seen with combined interventions $(p<0.05)$. Conclusion: In angiotensin-converting enzyme inhibitor-treated SNX animals, abrogation of sympathetic overactivity provides additional renoprotection and less nitro-oxidative stress of podocytes than single interventions. The added benefits were partially blood pressure independent.

Copyright $\odot 2007$ S. Karger AG, Basel

\section{Introduction}

The blood pressure-independent role of the renin-angiotensin system (RAS) in progressive deterioration of renal function has been firmly established in animal experiments $[1,2]$. In addition, in renal patients, angiotensin-converting enzyme (ACE) inhibitors as well as angiotensin receptor blockers have been shown to ameliorate progression [3-5].

\section{KARGER \\ Fax +41613061234 E-Mail karger@karger.ch} www.karger.com
(C) 2007 S. Karger AG, Basel

$1660-2129 / 07 / 1054-0124 \$ 23.50 / 0$

Accessible online at:

www.karger.com/nee
Péter Hamar, MD, PhD

Institute of Pathophysiology, Semmelweis University, Faculty of General Medicine Nagyvárad tér 4

HU-1089 Budapest (Hungary)

Tel./Fax +36 12100 100, E-Mail hampet@net.sote.hu 
Campese and colleagues $[6,7]$ documented activation of the sympathetic nervous system (SNS) in models of renal damage. Dorsal rhizotomy abrogated ascending stimulatory signals emanating from the kidney. This intervention reduced elevation of blood pressure and attenuated renal disease progression. In addition, blockade of sympathetic activity either by a central sympathetic inhibitor [8] or a $\beta$-blocker [9] attenuated progression independently of blood pressure in the remnant kidney model.

One of the main effects of the SNS in the kidney is activation of the juxtaglomerular apparatus [10]. It has remained undecided whether the beneficial effect of reduced sympathetic activity is mediated via reducing renin secretion from juxtaglomerular apparatus or whether the effect is renin-independent.

It has recently been emphasized that none of the current interventions including blockade of the RAS and of the SNS is completely effective in constantly abrogating progression [11]. It has therefore been argued that the interventional strategies of the future will presumably be combined interventions, e.g. RAS plus SNS or aldosterone receptor blockade [12].

These considerations prompted us to test the hypothesis whether the combination of ACE inhibition using quinapril and selective sympathetic denervation by dorsal rhizotomy is superior to the respective single interventions.

To test this hypothesis we analyzed renal morphology as well as the expression of fibrosis-related molecules (TGF- $\beta$, collagen IV) and nitro-oxidative stress (nitric oxide synthase isoforms, nitrotyrosine) mediators in the rat model of renal mass reduction.

\section{Materials and Methods}

\section{Experimental Design and Operative Procedures}

Twenty-week-old male Sprague-Dawley rats weighing 350$400 \mathrm{~g}$ were used (Charles River, Germany). All animals were housed under standard conditions (light on 08:00-20:00 h; 40$70 \%$ relative humidity, $22 \pm 1^{\circ} \mathrm{C}$ ), and had free access to water and chow (Altromin standard diet, Lage, Germany). All procedures were in accordance with the guidelines of the Institutional Animal Care and Use Committee. As shown in table 1, animals were randomly divided into 8 groups ( $n=18$ /group): 4 groups of animals underwent subtotal nephrectomy (SNX), and 4 groups were sham operated and served as controls (sham). In both SNX and sham groups, half of the animals were subjected to bilateral dorsal rhizotomy (T10-L2) or sham rhizotomy. In the groups of SNX and sham-operated animals, with or without rhizotomy, half of the animals received $10 \mathrm{mg} / \mathrm{kg}$ body weight/day quinapril dissolved in drinking water for 16 weeks. The drug concentration in the drinking fluid was adjusted according to the amount of water consumed. The above dose has been reported to cause effective suppression of the RAS. The control animals received tap water.

SNX was performed as described previously $[8,9]$. In brief, under ketamine + xylazine anesthesia (Ketanest $100 \mathrm{mg} / \mathrm{kg}$ body weight; Rompun $2 \mathrm{mg} / \mathrm{kg}$ body weight) the animals were uninephrectomized, i.e. the right kidney was decapsulated and removed by midline laparotomy. One week later, $2 / 3$ of the decapsulated left kidney was removed by resecting a specified amount of cortical tissue, leaving the pelvis and the hilus intact. Damage to the adrenals at decapsulation was carefully avoided. Gelaspon ${ }^{\circledR}$ (Chauvin Ankerpharm, Rudolfstadt, Germany) was used for hemostasis. The excised renal tissue was weighed on an analytic scale; a mean of $81 \pm 2 \%$ of the kidney cortex, which had undergone compensatory hypertrophy, was removed surgically. In sham-operated animals the kidneys were only decapsulated.

Dorsal rhizotomy was performed during the preceding uninephrectomy as described by Campese and Kogosov [6]. Briefly, from a dorsal incision, above the left kidney, the lumbar vertebral column was exposed by gently pulling the muscle away from the vertebrae. The dorsal roots were visualized and cut with fine scissors. Rhizotomy was performed at T10-L2, which contain the greatest concentration of afferent fibers from the kidneys to the brainstem. Animals were only included in the study, if all 5 dorsal roots could be identified on either side of the spine. Five animals were omitted from the study due to incomplete rhizotomy.

At week 16 the experiment was terminated. The animals were anesthetized with ketamine + xylazine, the aorta was cannulated and blood was obtained for chemistry. Blood pressure-controlled retrograde perfusion fixation was performed as described previously [13] and the remnant or control kidneys were further processed.

\section{Functional Measurements}

At the beginning and at the end of the study, 24-hour urine samples were collected using metabolic cages (Tecniplast, Buguggiate, Italy). At the end of the study, tail-cuff blood pressure was measured in all rats while conscious by electrosphygmomanometry (TSE, Bad Homburg, Germany) [14]. In addition, in 2 animals per group telemetric blood pressure was measured using the system of Data Sciences International (St. Paul, Minn., USA). Transmitters (TA11PA-C40) were implanted into the abdominal aorta. Implantation of the transmitters was performed as described elsewhere [8]. Receivers (RPC1) were placed underneath the cage. Mean, systolic, and diastolic arterial blood pressure and heart rate derived from the peak systolic blood pressure signal were recorded. Results are given as the mean of 150 -min readings on 3 consecutive days.

Urinary albumin excretion was determined using a microplate sandwich ELISA [15] modified by using a rabbit anti-rat albumin peroxidase conjugate.

\section{Tissue Preparation}

For morphometric analysis retrograde perfusion fixation with $3 \%$ glutaraldehyde was performed via the abdominal aorta in 7 animals per group $[8,9,13]$. The left remnants (or in sham-operated animals, the intact left kidneys) were harvested for morphometric and stereologic measurements. The kidneys were sectioned in a plane perpendicular to the interpolar axis, yielding slices of $1-\mathrm{mm}$ width. Ten small pieces of the kidney were selected by area- 
Table 1. Laboratory values and body weight at the time of harvest

\begin{tabular}{|c|c|c|c|c|c|c|c|c|c|}
\hline & Rhizotomy & $\begin{array}{l}\text { Creatinine } \\
\mathrm{mg} / \mathrm{dl}\end{array}$ & $\begin{array}{l}\text { Urea } \\
\mathrm{mg} / \mathrm{dl}\end{array}$ & $\begin{array}{l}\text { Hematocrit } \\
\%\end{array}$ & $\begin{array}{l}\text { Cholesterol } \\
\mathrm{mg} / \mathrm{dl}\end{array}$ & $\begin{array}{l}\text { LDL-C } \\
\mathrm{mg} / \mathrm{dl}\end{array}$ & $\begin{array}{l}\text { HDL-C } \\
\mathrm{mg} / \mathrm{dl}\end{array}$ & $\begin{array}{l}\text { Initial body } \\
\text { weight, g }\end{array}$ & $\begin{array}{l}\text { Body weight } \\
\text { at harvest, g }\end{array}$ \\
\hline \multicolumn{10}{|l|}{ Sham } \\
\hline \multirow[t]{2}{*}{ Water } & $-(\mathrm{n}=12)$ & $0.4 \pm 0.1$ & $40.0 \pm 4.3$ & $42.7 \pm 3.1$ & $68.8 \pm 15.7$ & $9.1 \pm 7.1$ & $48.9 \pm 8.9$ & $399 \pm 12.9$ & $588 \pm 46.8$ \\
\hline & $+(\mathrm{n}=12)$ & $0.4 \pm 0.1$ & $41.8 \pm 4.9$ & $44.3 \pm 3.4$ & $72.9 \pm 10.0$ & $7.4 \pm 4.8$ & $51.4 \pm 8.5$ & $387 \pm 27.8$ & $562 \pm 33.1$ \\
\hline \multirow[t]{2}{*}{ Quinapril } & $-(\mathrm{n}=12)$ & $0.4 \pm 0.0$ & $51.6 \pm 9.1$ & $44.6 \pm 3.4$ & $74.3 \pm 14.0$ & $10.9 \pm 6.8$ & $50.8 \pm 10.2$ & $385 \pm 14.6$ & $548 \pm 21.6$ \\
\hline & $+(\mathrm{n}=12)$ & $0.4 \pm 0.1$ & $49.6 \pm 6.0$ & $40.3 \pm 3.3$ & $72.0 \pm 18.6$ & $6.1 \pm 6.3$ & $53.1 \pm 12.3$ & $385 \pm 21.4$ & $589 \pm 42.9$ \\
\hline \multicolumn{10}{|l|}{$S N X$} \\
\hline \multirow[t]{2}{*}{ Water } & $-(\mathrm{n}=12)$ & $1.0 \pm 0.2^{\mathrm{a}}$ & $113.1 \pm 7.9^{\mathrm{a}}$ & $36.1 \pm 5.1^{\mathrm{a}}$ & $131.3 \pm 13.9^{a}$ & $19.1 \pm 6.3^{\mathrm{a}}$ & $97.9 \pm 13.4^{\mathrm{a}}$ & $391 \pm 12.7$ & $557 \pm 27.4$ \\
\hline & $+(\mathrm{n}=17)$ & $0.7 \pm 0.4^{\mathrm{b}}$ & $97.1 \pm 15.0^{\mathrm{b}}$ & $36.9 \pm 3.4$ & $113.3 \pm 41.0$ & $16.6 \pm 16.6$ & $80.1 \pm 28.0$ & $394 \pm 26.6$ & $573 \pm 33.8$ \\
\hline \multirow[t]{2}{*}{ Quinapril } & $-(\mathrm{n}=17)$ & $0.9 \pm 0.01^{\mathrm{a}}$ & $123.4 \pm 13.9^{\mathrm{a}}$ & $37.0 \pm 1.5$ & $109.1 \pm 21.7$ & $16.4 \pm 7.6$ & $80.4 \pm 17.4$ & $394 \pm 10.3$ & $546 \pm 18.6$ \\
\hline & $+(\mathrm{n}=17)$ & $0.75 \pm 0.3^{b}$ & $106.6 \pm 13.4^{\mathrm{b}}$ & $38.9 \pm 4.4^{\mathrm{b}}$ & $100.1 \pm 28.7^{\mathrm{b}}$ & $13.4 \pm 5.0^{\mathrm{b}}$ & $77.7 \pm 12.9^{b}$ & $382 \pm 16.9$ & $522 \pm 42.3$ \\
\hline ANOVA & & $\mathrm{p}<0.001$ & $\mathrm{p}<0.001$ & $\mathrm{p}<0.001$ & $\mathrm{p}<0.001$ & $\mathrm{p}<0.001$ & $\mathrm{p}<0.001$ & n.s. & n.s. \\
\hline
\end{tabular}

${ }^{\mathrm{a}} \mathrm{p}<0.01$ vs. sham + no intervention or respective control group; ${ }^{\mathrm{b}} \mathrm{p}<0.05 \mathrm{vs}$. SNX + no intervention. $+=$ Animals with rhizotomy; $-=$ animals with sham rhizotomy.

weighted sampling and embedded in Epon-Araldite. Semithin $(1 \mu \mathrm{m})$ and ultrathin sections $(0.08 \mu \mathrm{m})$ were prepared and stained with methylene blue/basic fuchsine or lead citrate/uranyl acetate, respectively. The remaining tissue slices were embedded in paraffin; $4-\mu \mathrm{m}$ sections were stained with hematoxylin/eosin and periodic acid-Schiff (PAS).

For immunohistochemical analysis, the experiments were repeated and were terminated with perfusion of the kidney with icecold $\mathrm{NaCl}$. Half of the saline-perfused kidneys were immersion fixed in $4 \%$ buffered formaldehyde, embedded in paraffin, and cut into $4-\mu \mathrm{m}$-thick sections. The other half of the kidneys were snapfrozen in liquid nitrogen-cooled isopentane for mRNA expression analysis.

Paraffin sections were prepared and incubated with antibodies, using the avidin-biotin method [13], to detect the following epitopes: TGF- $\beta_{1}$ (anti-TGF- $\beta_{1}$ rabbit IgG polyclonal antibody, 1:50; Santa Cruz Biotechnology, Santa Cruz, Calif., USA), collagen IV (anti-collagen IV rabbit polyclonal antibody, 1:40, Biotrend Chemikalien, Cologne, Germany), endothelial nitric oxide synthase [NOS-3 (eNOS), anti-eNOS rabbit polyclonal antibody, 1:400; ABR-Affinity BioReagents, Golden, Colo., USA], neuronal nitric oxide synthase [NOS-1 (nNOS), anti-nNOS rabbit polyclonal antibody, 1:50, BD Pharmingen, Heidelberg, Germany] and nitrotyrosine (sheep polyclonal antibody, 1:400, Oxis Research, Portland, Oreg., USA).

\section{Morphometric and Stereologic Investigations}

Indices of Renal Damage. The glomerulosclerosis index was assessed on PAS-stained paraffin sections according to the scoring system (scores: 0-4) of el Nahas et al. [16]. Using light microscopy and a magnification of $\times 400$ the glomerular score of each animal was derived as the arithmetic mean of 100 glomeruli. The tubular, interstitial and vascular damage scores were assessed on PAS-stained paraffin sections using a similar scoring system (score $0-4$ ) at a magnification of $\times 100$ as described in detail elsewhere [8].
Glomerular Geometry. Area density of the glomerular tuft $\left(\mathrm{A}_{\mathrm{AT}}\right)$ and volume density of glomeruli $\left(\mathrm{V}_{\mathrm{V}}\right)$ were measured by the point counting method with point density $=$ area density $=$ volume density $\left(\mathrm{P}_{\mathrm{P}}=\mathrm{A}_{\mathrm{A}}=\mathrm{V}_{\mathrm{V}}\right)$ using a 100 -point Zeiss eyepiece (Integrationsplatte II; Zeiss, Oberkochen, Germany) at a magnification of $\times 400$ on PAS sections. In addition, the number of glomeruli per area $\left(\mathrm{N}_{\mathrm{A}}\right)$ was counted [for detailed description of analysis of glomerular geometry, see 13]. Briefly, from the above data the number of glomeruli per volume $\left[\mathrm{N}_{\mathrm{V}}=(1 / 1.382) \times\left(\mathrm{N}_{\mathrm{A}}{ }^{1.5} \times \mathrm{V}_{\mathrm{V}}{ }^{0.5}\right)\right]($ corrected for tissue shrinkage: $45 \%$ ) and total cortex volume was calculated from kidney mass (KW), specific weight of the kidney $\left(\mathrm{SW}_{\mathrm{K}}\right)$, and volume density of the cortex according to $\mathrm{V}_{\mathrm{Cortex}}=$ $\mathrm{KW} / \mathrm{SW}_{\mathrm{K}} \times \mathrm{V}_{\text {VCortex }}\left(\mathrm{V}_{\text {Cortex }}\right)=(1 / 1.382) \times\left(\mathrm{N}_{\mathrm{A}}^{1.5} \times \mathrm{V}_{\mathrm{V}}^{0.5}\right)$. From these parameters the total number of glomeruli was derived $\left(\mathrm{N}_{\mathrm{Glom}}=\mathrm{N}_{\mathrm{V}} \times \mathrm{V}_{\text {Cortex }}\right)$. Finally, the mean glomerular tuft volume: $\left.\mathrm{mV}_{\mathrm{Glom}}=(1 / 1.382) \times \mathrm{A}_{\mathrm{T}}{ }^{1.5}\right)$ was calculated from the total area of the glomerular tuft and cortex area $\left(\mathrm{A}_{\mathrm{T}}=\mathrm{A}_{\mathrm{AT}} \times \mathrm{A}_{\text {Cortex }}\right)$. The number of glomeruli $\left(\mathrm{N}_{\mathrm{Glom}}\right)$ per kidney was used to estimate the extent of surgical nephron reduction and the mean glomerular tuft volume ( $\left.\mathrm{mV}_{\mathrm{Glom}}\right)$ was used to estimate the extent of glomerular enlargement. Glomerular mesangial matrix volume $\left(\mathrm{V}_{\text {Matrix }}\right)$ was calculated as the fractional mesangial matrix volume of the glomerular capillary tuft (points on the matrix/points on the whole glomerular tuft) and is given as percent.

Glomerular Capillaries. In 5 semithin sections per animal glomerular cell number and volume were analyzed using an eyepiece for point counting (see above) at a magnification of $\times 1,000$ (oil immersion). Briefly, the length density of glomerular capillaries $\left(\mathrm{L}_{\mathrm{V}}: \mathrm{mm}\right.$ capillary $/ \mathrm{mm}^{3}$ glomerular tuft volume) was determined according to the standard stereologic formula $\left(\mathrm{L}_{\mathrm{V}}=2 \mathrm{Q}_{\mathrm{A}}\right.$ : the number of capillary transects per area of the capillary tuft). This parameter gives the average capillary length normalized to glomerular volume to exclude the effect of hypertrophy; thus it is a marker of glomerular capillary obliteration [17]. Furthermore, glomerular capillary length for the whole kidney $\left(\mathrm{L}_{\mathrm{c}}\right)$, i.e. total capillary length, was determined. Glomerular capillary tuft volume $\left(\mathrm{V}_{\text {Tuft }}\right)$ was cal- 
culated as the fractional capillary tuft volume of the whole glomerulus (points on the tuft/points on the whole glomerulus) and is given as percent.

Glomerular Cellularity. The number per glomerulus and mean volume of glomerular cells (podocytes, mesangial and endothelial cells) was analyzed in 15 glomeruli per animal. The mean cell number/glomerulus $\left(\mathrm{N}_{\mathrm{C}}\right)$ was calculated from cell density per volume $\left(\mathrm{Nc}_{\mathrm{v}}\right)$ and volume density of the respective cell type $\left(\mathrm{Vc}_{\mathrm{v}}\right) \mathrm{ac}-$ cording to the equation: $\mathrm{Nc}_{\mathrm{v}}=\mathrm{k} / \beta \times \mathrm{Nc}_{\mathrm{A}}{ }^{1.5} / \mathrm{Vc}_{\mathrm{v}}{ }^{0.5}$ with $\mathrm{k}=1$ and $\beta=1.5$ for podocytes and 1.4 for mesangial and endothelial cells. The respective mean cell volumes were calculated according to the equation $\mathrm{mV}_{\mathrm{c}}=\mathrm{Vc}_{\mathrm{v}} \times \mathrm{mV}_{\text {glom }}[18]$.

\section{Real-Time PCR}

Total RNA was isolated from whole kidneys using SV Total RNA Isolation System (Promega, Mannheim, Germany) according to the manufacturer's instructions. RNA concentration was determined photometrically. Reverse transcription was performed with the 1st Strand cDNA Synthesis Kit (AMV) from Roche (Roche Diagnostics, Mannheim, Germany) using $1 \mu \mathrm{g}$ RNA and random primers (final concentration: $3.2 \mu \mathrm{g}$ ).

All PCR reactions were performed on a LightCycler (Roche Diagnostics, Mannheim, Germany) using the LightCycler-Faststart DNA Master SYBR Green I Kit (Roche). The samples were quantified normalizing to glyceraldehyde-3-phosphate dehydrogenase $(\mathrm{GAPDH})$ expression. Primer sequences were as follows: TGF- $\beta_{1}$ forward 5'-CACCATCCATGACATGAACC-3', reverse 5'-TCATGTTGGACAACTGCTCC-3'; NOS-3 (eNOS) forward 5'-TGACCCTCACCGATACAACA-3', reverse 5'-CTGGCCTTCTGCTCATTTTC-3'. Specificity of the PCR reaction was confirmed with melting curve analysis. Every sample was quantified using a gene-specific standard curve, and the mean value of three different PCR runs was taken for statistical evaluation.

\section{Immunohistochemistry}

TGF- $\beta_{1}$, collagen IV, NOS-1 (nNOS), NOS-3 (eNOS) and nitrotyrosine immunohistochemical reactivity were examined with light microscopy at a magnification of $\times 400$. Scoring (scores $0-4$; $0=$ no staining, 1 = weak, $2=$ mild, $3=$ strong, $4=$ very strong staining) was performed as described elsewhere [13].

\section{Statistics}

Data are presented as mean \pm standard deviation (SD). Randomly selected animals $(n=7)$ were used for morphometric analysis. After testing for normal distribution, the Kruskal-Wallis test or one-way ANOVA were chosen for analysis of variance, followed by Duncan's multiple range test, to test for differences between groups. The zero hypothesis was rejected if the probability of error (p) was less than 0.05 .

\section{Results}

\section{Animal Data (table 1)}

At the time of operation the body weight of the animals was comparable in all groups. At the end of the study average body weight was also similar. SNX rats had significantly higher serum creatinine and serum urea concentrations than sham-operated animals. The values were significantly lower in the animals on combined intervention. Comparing the 2 single intervention groups, retention parameters tended to be lower in the rhizotomy animals versus quinapril monotherapy. In SNX animals the hematocrit values were significantly lower and serum cholesterol significantly higher, the latter mainly as the result of increased LDL cholesterol. Both parameters were significantly improved by combined intervention.

During the study, none of the sham-operated animals died. Six out of 18 SNX without interventions died, but only 1 in each of the respective SNX groups with intervention.

\section{Albuminuria and Blood Pressure (table 2, fig. 1)}

At the end of the study albuminuria was strikingly higher in untreated SNX and significantly lower after rhizotomy alone. It was also lower in SNX on quinapril and lowest on combined intervention (quinapril plus rhizotomy).

Tail plethysmography overestimated blood pressure. Blood pressure was monitored by telemetry in a limited number of animals. The results (fig. 1) indicated higher blood pressure in untreated SNX and lower values in treated SNX.

\section{Indices of Renal Damage (table 3, fig. 2, 3)}

In untreated SNX, indices of glomerular, tubular, interstitial and vascular damage (VDI) were all significantly higher than in sham-operated rats. Rhizotomy had a marked effect on all indices except VDI. The effect of quinapril monotherapy was even more striking (with the exception of VDI), but with exception of VDI combined intervention yielded the best outcome $(\mathrm{p}<0.05)$.

\section{Stereologic Measurements (table 4)}

SNX consistently reduced the number of glomeruli to a similar extent documenting the homogeneity of the SNX groups. In all SNX groups a compensatory increase in glomerular volume was noted which was significantly lower after quinapril. The length density of glomerular capillaries as well as the total length of capillaries per remnant kidney was significantly less after SNX reflecting capillary loss or obliteration as a result of glomerulosclerosis. Rhizotomy, but not quinapril, almost normalized capillary length density. In SNX the matrix represented a significantly greater proportion of the tuft, reflecting glomerular extracellular matrix accumulation. The matrix/tuft ratio was significantly lower in quinapriltreated SNX, but was not affected by rhizotomy. 
Table 2. Albuminuria, systolic blood pressure and kidney weight relative to body weight at study termination (4 months)

\begin{tabular}{|c|c|c|c|c|}
\hline & Rhizotomy & $\begin{array}{l}\text { Albuminuria } \\
\mathrm{mg} / 24 \mathrm{~h}\end{array}$ & $\begin{array}{l}\text { Systolic blood pressure } \\
\text { (tail plethysmography) } \\
\text { mm Hg }\end{array}$ & $\begin{array}{l}\mathrm{KW} / \mathrm{BW} \\
\%\end{array}$ \\
\hline \multicolumn{5}{|l|}{ Sham } \\
\hline \multirow[t]{2}{*}{ Water } & $-(\mathrm{n}=12)$ & $4 \pm 2$ & $129 \pm 12$ & $0.36 \pm 0.02$ \\
\hline & $+(\mathrm{n}=12)$ & $2 \pm 1$ & $125 \pm 30$ & $0.41 \pm 0.04$ \\
\hline \multirow[t]{2}{*}{ Quinapril } & $-(\mathrm{n}=12)$ & $2 \pm 1$ & $115 \pm 13$ & $0.33 \pm 0.03$ \\
\hline & $+(\mathrm{n}=12)$ & $1 \pm 1$ & $114 \pm 10$ & $0.39 \pm 0.03$ \\
\hline \multicolumn{5}{|l|}{ SNX } \\
\hline \multirow[t]{2}{*}{ Water } & $-(\mathrm{n}=12)$ & $169 \pm 75^{\mathrm{a}}$ & $162 \pm 13^{\mathrm{a}}$ & $0.49 \pm 0.1^{\mathrm{a}}$ \\
\hline & $+(\mathrm{n}=17)$ & $86 \pm 45^{b}$ & $138 \pm 28^{b}$ & $0.45 \pm 0.07$ \\
\hline \multirow[t]{2}{*}{ Quinapril } & $-(\mathrm{n}=17)$ & $15 \pm 23^{c}$ & $115 \pm 12^{\mathrm{c}}$ & $0.44 \pm 0.09$ \\
\hline & $+(\mathrm{n}=17)$ & $5 \pm 4^{\mathrm{c}, \mathrm{d}(\mathrm{n} . \mathrm{s} .)}$ & $112 \pm 14^{\mathrm{c}(\text { n.s. })}$ & $0.42 \pm 0.05$ \\
\hline ANOVA & & $\mathrm{p}<0.001$ & $\mathrm{p}<0.001$ & $\mathrm{p}<0.001$ \\
\hline
\end{tabular}

${ }^{\mathrm{a}} \mathrm{p}<0.05$ vs. sham + no intervention; ${ }^{\mathrm{b}} \mathrm{p}<0.05$ vs. SNX + no intervention; ${ }^{\mathrm{c}} \mathrm{p}<0.01$ vs. SNX + no intervention; ${ }^{\mathrm{d}} \mathrm{p}<0.05$ vs. SNX + quinapril + sham rhizotomy. KW $=$ Kidney weight; $\mathrm{BW}=$ body weight; $+=$ animals with rhizotomy, $-=$ animals with sham rhizotomy; n.s. = nonsignificant: SNX + quinapril + rhizotomy vs. sham + quinapril + rhizotomy.

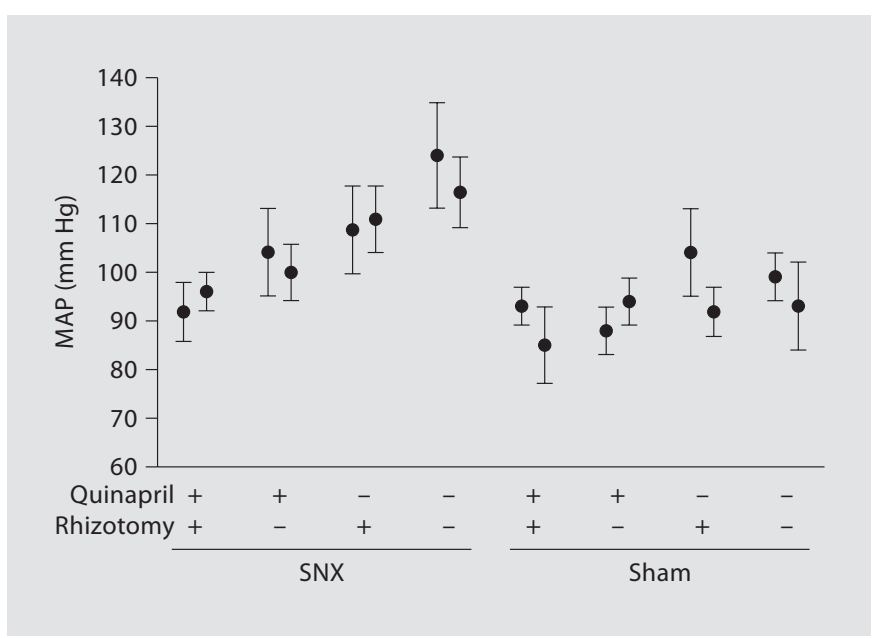

Fig. 1. Telemetrically measured mean arterial pressure in 2 animals per experimental group. Bars represent 15 measurements on 3 consecutive days in individual animals (mean \pm SD of individual values).

\section{Cellular Analysis of the Glomerulus (table 5)}

In this model of renal damage of moderate severity, the number of endothelial cells was also strikingly increased in untreated SNX, but significantly lower in quinapril-treated SNX, but not in SNX with rhizotomy. There was no significant change in endothelial cell volume. Finally, in SNX a significant increase in mesangial cell number was noted, which again was attenuated, but not normalized, by quinapril. Rhizotomy did not affect this parameter. No significant changes of mesangial cell volume were noted.

Of particular interest are the podocyte findings. The number of podocytes per glomerulus remained unchanged, but the podocyte volume was strikingly increased in SNX. It was significantly lower in the quinapril group, but not affected by rhizotomy

\section{Immunohistochemistry and Real-Time PCR Analysis of} the Kidneys (tables 6, 7)

Increased collagen was found in glomeruli (table 6) and was significantly reduced by quinapril plus rhizotomy. Tubulointerstitial collagen deposition was prevented by all interventions. Interestingly, rhizotomy as a single intervention prevented tubulointerstitial collagen deposition more effectively than quinapril monotherapy.

Glomerular TGF- $\beta_{1}$ expression (fig. 4) was only reduced by combined intervention, but not by quinapril or rhizotomy (table 6).

Combined interventions, but not single interventions, normalized protein expression of NOS-3 (eNOS) in glomeruli (table 7). A similar trend was seen with NOS-3 mRNA, but the differences between the groups were not significant.

The protein level expression of NOS-1 (nNOS) in macula densa cells was reduced in SNX. It was unaffected by 
Table 3. Morphologic indices of renal damage

\begin{tabular}{|c|c|c|c|c|c|}
\hline & Rhizotomy & $\begin{array}{l}\text { Glomerulosclerosis } \\
\text { index }\end{array}$ & $\begin{array}{l}\text { Tubular } \\
\text { damage index }\end{array}$ & $\begin{array}{l}\text { Interstitial } \\
\text { damage index }\end{array}$ & $\begin{array}{l}\text { Vascular } \\
\text { damage index }\end{array}$ \\
\hline \multicolumn{6}{|l|}{ Sham } \\
\hline \multirow[t]{2}{*}{ Water } & $-(\mathrm{n}=7)$ & $0.14 \pm 0.04$ & $0.55 \pm 0.31$ & $0.11 \pm 0.14$ & $0.20 \pm 0.28$ \\
\hline & $+(\mathrm{n}=7)$ & $0.13 \pm 0.04$ & $0.26 \pm 0.12$ & $0.16 \pm 0.17$ & $0.07 \pm 0.15$ \\
\hline \multirow[t]{2}{*}{ Quinapril } & $-(\mathrm{n}=7)$ & $0.31 \pm 0.19$ & $0.43 \pm 0.17$ & $0.14 \pm 0.11$ & $0.02 \pm 0.05$ \\
\hline & $+(\mathrm{n}=7)$ & $0.36 \pm 0.17$ & $0.29 \pm 0.16$ & $0.08 \pm 0.10$ & $0.10 \pm 0.14$ \\
\hline \multicolumn{6}{|l|}{ SNX } \\
\hline \multirow[t]{2}{*}{ Water } & $-(\mathrm{n}=7)$ & $1.40 \pm 0.6^{\mathrm{a}}$ & $1.82 \pm 0.67^{\mathrm{a}}$ & $1.78 \pm 0.60^{\mathrm{a}}$ & $0.42 \pm 0.17^{\mathrm{a}}$ \\
\hline & $+(\mathrm{n}=7)$ & $0.80 \pm 0.23^{b}$ & $1.46 \pm 0.13$ & $0.75 \pm 0.25^{\mathrm{b}}$ & $0.40 \pm 0.29$ \\
\hline \multirow[t]{2}{*}{ Quinapril } & $-(\mathrm{n}=7)$ & $0.37 \pm 0.16^{\mathrm{b}}$ & $1.14 \pm 0.18^{\mathrm{b}}$ & $0.48 \pm 0.15^{\mathrm{b}}$ & $0.45 \pm 0.31$ \\
\hline & $+(n=7)$ & $0.31 \pm 0.15^{\mathrm{c}(\text { n.s. })}$ & $0.55 \pm 0.37^{\text {c, }} \mathrm{d}$ (n.s.) & $0.15 \pm 0.13^{\text {c, d (n.s.) }}$ & $0.12 \pm 0.05^{\text {b (n.s.) }}$ \\
\hline ANOVA & & $\mathrm{p}<0.001$ & $\mathrm{p}<0.001$ & $\mathrm{p}<0.001$ & $\mathrm{p}<0.001$ \\
\hline
\end{tabular}

${ }^{a} \mathrm{p}<0.05$ vs. sham + no intervention; ${ }^{\mathrm{b}} \mathrm{p}<0.05$ vs. SNX + no intervention; ${ }^{\mathrm{c}} \mathrm{p}<0.01 \mathrm{vs}$. SNX + no intervention; ${ }^{\mathrm{d}} \mathrm{p}<0.05$ vs. SNX + quinapril + sham rhizotomy. + = Animals with rhizotomy; $-=$ animals with sham rhizotomy; n.s. = nonsignificant: SNX + quinapril + rhizotomy vs. sham + quinapril + rhizotomy.

rhizotomy and quinapril, but was normalized by combined intervention (table 7).

Nitrotyrosine staining as a marker of oxidative stress of podocytes was more intense in untreated SNX rats compared to sham-operated rats (table 7). It was not affected by rhizotomy, but reduced to some extent by quinapril and completely normalized by combined intervention (fig. 5).

\section{Discussion}

The salient result of the present study is the finding that in the remnant kidney model of the rat the combined intervention of ACE inhibition plus rhizotomy (to eliminate renal sympathetic innervation) is superior to the respective single interventions. Combined intervention yielded the best indices of renal damage, i.e. albuminuria, glomerulosclerosis index, glomerular and tubulointerstitial TGF- $\beta$ expression and collagen deposition, nitrotyrosine staining of podocytes, and NOS-3 (eNOS) expression.

In the surgical renal ablation model high-dose ACE inhibitor strikingly attenuated the development of glomerulosclerosis as well as tubular and interstitial damage, confirming previous results. In ACE inhibitortreated animals podocyte volume and mesangial cell numbers were strikingly lower. Furthermore we saw diminished TGF- $\beta_{1}$ expression and less staining for nitrotyrosine in podocytes.

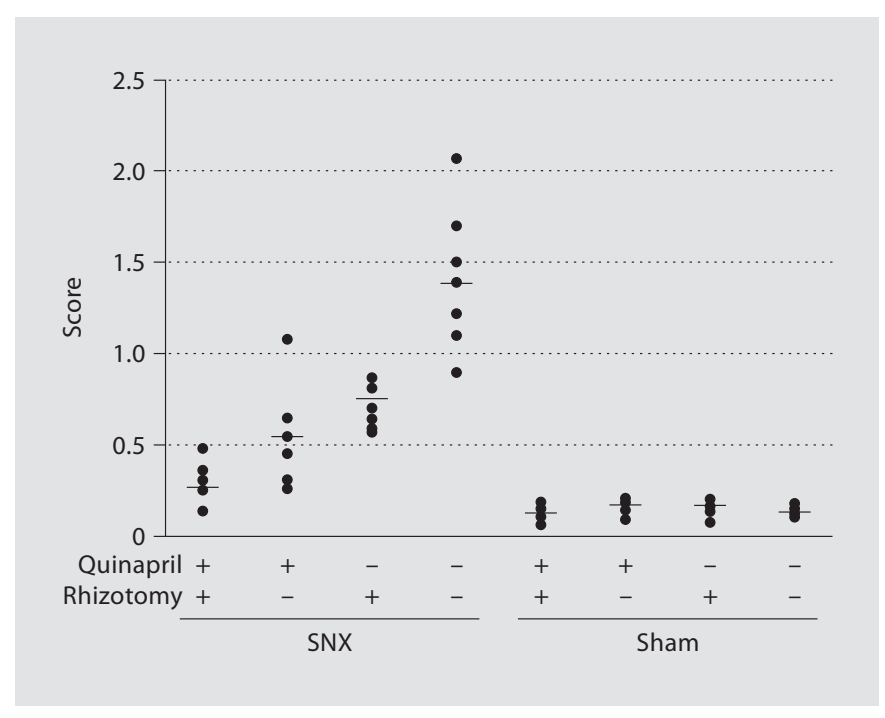

Fig. 2. Individual values of glomerulosclerosis index.

Elimination of sympathetic activity by rhizotomy, i.e. through the interruption of the afferent sympathicostimulatory signals emanating from the kidney, had strikingly beneficial effects on glomerulosclerosis and indices of interstitial damage. Rhizothomy also led to greater length density and total length of glomerular capillaries. This finding is consistent with the observation that sympathetic activity suppresses capillary formation in the heart 

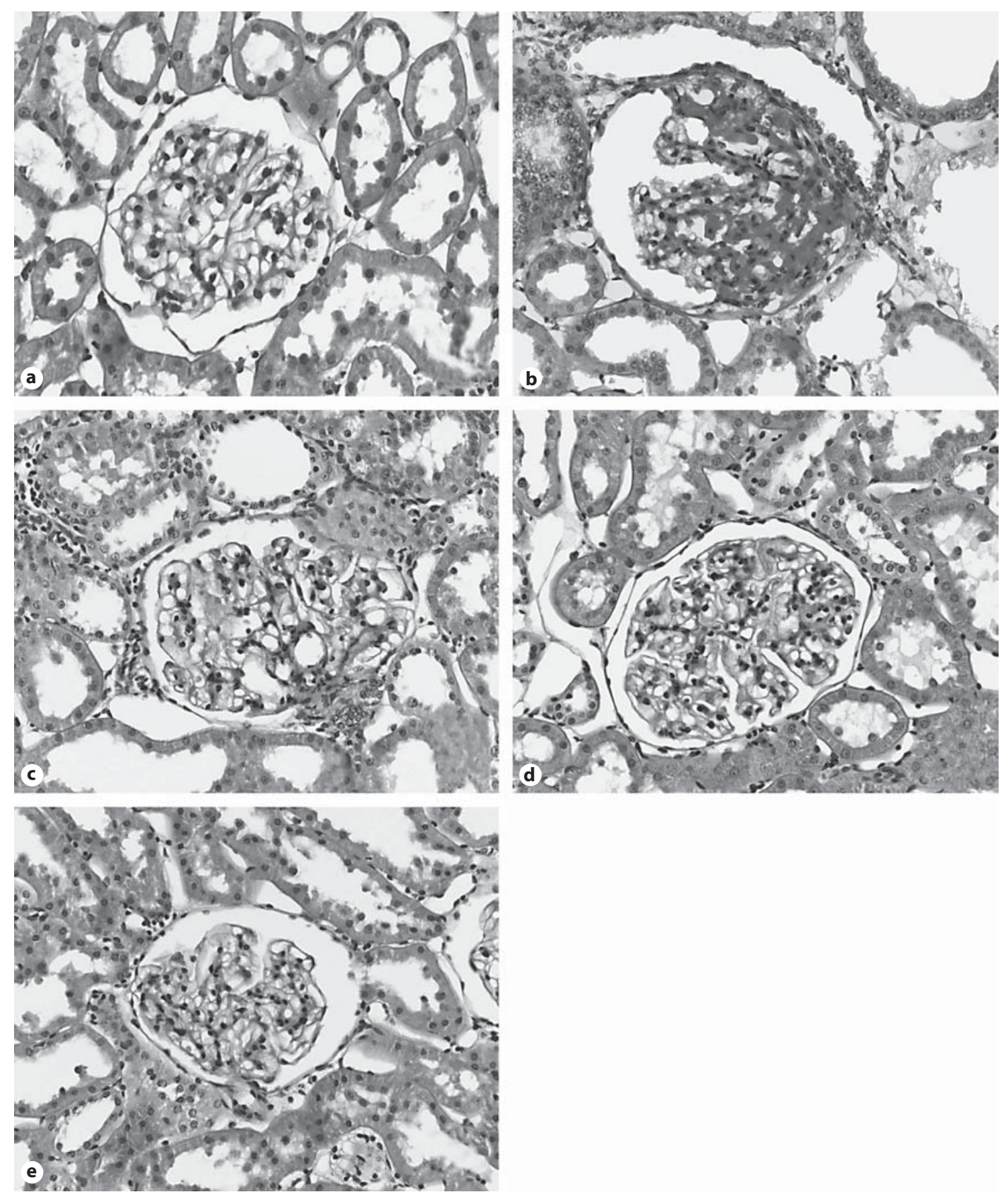

Fig. 3. Representative photographs of glomeruli from a sham-nephrectomized animal (a) and SNX animals (b-e). b SNX: water, sham rhizotomy. c SNX: quinapril, sham rhizotomy. d SNX: water, rhizotomy. e SNX: quinapril, rhizotomy. PAS stain. Magnification $\times 400$.

[19]. These findings were accompanied by markedly lower albuminuria. SNS inhibition proved to be more protective than renin-angiotensin-aldosterone system (RAAS) inhibition in preventing interstitial collagen deposition and the rise of retention parameters (serum creatinine, BUN).

In addition, rhizotomy amplified the beneficial effects of ACE inhibitor. Albuminuria was significantly 
Table 4. Stereologic analysis of glomeruli

\begin{tabular}{|c|c|c|c|c|c|c|}
\hline & \multirow[t]{2}{*}{ Rhizotomy } & \multicolumn{2}{|c|}{ Glomerular geometry } & \multicolumn{2}{|c|}{ Glomerular capillaries } & \multirow{2}{*}{$\begin{array}{l}\text { Glomerular matrix: } \\
\mathrm{V}_{\text {Matrix }} \% / \mathrm{V}_{\text {Tuft }}\end{array}$} \\
\hline & & $\mathrm{N}_{\text {Glom }}$ & $\begin{array}{l}\mathrm{mV}_{\mathrm{Glom}} \\
\times 10^{6} \mu \mathrm{m}^{3}\end{array}$ & $\begin{array}{l}\text { length densi } \\
\mathrm{mm} / \mathrm{mm}^{3}\end{array}$ & total length, m & \\
\hline \multicolumn{7}{|l|}{ Sham } \\
\hline \multirow[t]{2}{*}{ Water } & $-(\mathrm{n}=7)$ & $45,011 \pm 9,939$ & $2.6 \pm 2.2$ & $6.3 \pm 1.3$ & $6,925 \pm 1,964$ & $13.7 \pm 0.8$ \\
\hline & $+(\mathrm{n}=7)$ & $49,190 \pm 11,343$ & $3.0 \pm 1.9$ & $6.5 \pm 1.0$ & $7,519 \pm 770$ & $16.2 \pm 6.7$ \\
\hline \multirow[t]{2}{*}{ Quinapril } & $-(\mathrm{n}=7)$ & $45,030 \pm 5,389$ & $2.8 \pm 2.5$ & $5.5 \pm 1.2$ & $6,072 \pm 421$ & $12.9 \pm 0.8$ \\
\hline & $+(n=7)$ & $62,020 \pm 9,826$ & $2.7 \pm 2.3$ & $6.4 \pm 0.5$ & $7,580 \pm 1,401$ & $13.4 \pm 1.2$ \\
\hline \multicolumn{7}{|l|}{ SNX } \\
\hline \multirow[t]{2}{*}{ Water } & $-(\mathrm{n}=7)$ & $18,024 \pm 3,290^{\mathrm{a}}$ & $7.3 \pm 1.6^{\mathrm{a}}$ & $4.3 \pm 0.2^{\mathrm{a}}$ & $3,906 \pm 759^{a}$ & $23.0 \pm 1.4^{\mathrm{a}}$ \\
\hline & $+(n=7)$ & $19,136 \pm 5,180$ & $6.4 \pm 2.2$ & $5.1 \pm 0.3^{b}$ & $5,302 \pm 1,486^{\mathrm{b}}$ & $23.6 \pm 3.5^{\mathrm{a}}$ \\
\hline \multirow[t]{2}{*}{ Quinapril } & $-(\mathrm{n}=7)$ & $23,089 \pm 5,959$ & $5.0 \pm 3.2^{\mathrm{b}}$ & $4.5 \pm 0.4$ & $3,653 \pm 989$ & $14.9 \pm 0.4^{\text {b (n.s.) }}$ \\
\hline & $+(\mathrm{n}=7)$ & $19,896 \pm 3,704$ & $4.5 \pm 1.7^{\mathrm{b}}$ & $5.0 \pm 0.7^{b}$ & $5,549 \pm 2,208^{b}$ & $14.1 \pm 0.8^{\mathrm{b}(\mathrm{n} . \mathrm{s} .)}$ \\
\hline \multicolumn{2}{|l|}{ ANOVA } & $\mathrm{p}<0.001$ & $\mathrm{p}<0.001$ & $\mathrm{p}<0.001$ & $\mathrm{p}<0.001$ & $\mathrm{p}<0.001$ \\
\hline
\end{tabular}

Table 5. Cellular analysis of the glomerulus

\begin{tabular}{|c|c|c|c|c|c|c|c|}
\hline & \multirow[t]{2}{*}{ Rhizotomy } & \multicolumn{2}{|c|}{ Endothelial cells } & \multicolumn{2}{|c|}{ Mesangial cells } & \multicolumn{2}{|l|}{ Podocytes } \\
\hline & & $\begin{array}{l}\text { number/ } \\
\text { glomerulus }\end{array}$ & $\begin{array}{l}\text { mean } \\
\text { volume, } \mathrm{mm}^{3}\end{array}$ & $\begin{array}{l}\text { number/ } \\
\text { glomerulus }\end{array}$ & $\begin{array}{l}\text { mean } \\
\text { volume, } \mathrm{mm}^{3}\end{array}$ & $\begin{array}{l}\text { number/ } \\
\text { glomerulus }\end{array}$ & $\begin{array}{l}\text { mean } \\
\text { volume, } \mathrm{mm}^{3}\end{array}$ \\
\hline \multicolumn{8}{|l|}{ Sham } \\
\hline \multirow[t]{2}{*}{ Water } & $-(n=7)$ & $446 \pm 76$ & $181 \pm 43$ & $364 \pm 84$ & $210 \pm 51$ & $109 \pm 6$ & $796 \pm 71$ \\
\hline & $+(n=7)$ & $500 \pm 62$ & $166 \pm 50$ & $356 \pm 42$ & $291 \pm 118$ & $106 \pm 10$ & $810 \pm 41$ \\
\hline \multirow[t]{2}{*}{ Quinapril } & $-(n=7)$ & $490 \pm 60$ & $147 \pm 51$ & $273 \pm 82$ & $279 \pm 90$ & $110 \pm 4$ & $719 \pm 39$ \\
\hline & $+(n=7)$ & $511 \pm 58$ & $132 \pm 11$ & $342 \pm 28$ & $258 \pm 48$ & $106 \pm 2$ & $806 \pm 59$ \\
\hline \multicolumn{8}{|l|}{ SNX } \\
\hline \multirow[t]{2}{*}{ Water } & $-(\mathrm{n}=7)$ & $852 \pm 128^{a}$ & $177 \pm 29$ & $867 \pm 211^{\mathrm{a}}$ & $311 \pm 88$ & $123 \pm 3$ & $2,299 \pm 146^{\mathrm{a}}$ \\
\hline & $+(\mathrm{n}=7)$ & $1,018 \pm 212$ & $140 \pm 49$ & $816 \pm 181$ & $239 \pm 103$ & $109 \pm 1$ & $2,217 \pm 149$ \\
\hline \multirow[t]{2}{*}{ Quinapril } & $-(\mathrm{n}=7)$ & $590 \pm 78^{b}$ & $173 \pm 28$ & $551 \pm 70^{\mathrm{b}}$ & $250 \pm 54$ & $112 \pm 6$ & $1,818 \pm 171^{b}$ \\
\hline & $+(n=7)$ & $630 \pm 13^{b}$ & $161 \pm 21$ & $479 \pm 86^{b}$ & $300 \pm 22$ & $106 \pm 3$ & $1,840 \pm 80^{\mathrm{b}}$ \\
\hline ANOVA & & $\mathrm{p}<0.001$ & n.s. & $\mathrm{p}<0.001$ & n.s. & n.s. & $\mathrm{p}<0.001$ \\
\hline
\end{tabular}

${ }^{\mathrm{a}} \mathrm{p}<0.01$ vs. sham + no intervention; ${ }^{\mathrm{b}} \mathrm{p}<0.05$ vs. SNX + no intervention. $+=$ Animals with rhizotomy; - = animals with sham rhizotomy.

lower in SNX rats with quinapril plus rhizotomy. Tubular and interstitial damage indices were also significantly lower than in SNX on quinapril monotherapy. Additional benefit of SNS inhibition over intense RAAS inhibition suggests RAAS-independent beneficial effects of SNS inhibition.

ACE Inhibition and Rhizotomy in Progression
Several points of the experiment deserve comment. We deliberately used a model of moderate ablation of cortical mass by surgical resection causing reproducible reduction of the number of glomeruli (table 4). Resection involved the outer cortex, so that the kidney remnant contained a disproportionate number of juxtamedullary 
Table 6. Immunohistochemical analysis of fibrosis markers (mean score \pm SD) and TGF- $\beta_{1}$ real-time PCR results in the whole kidney (mean relative expression level \pm SD)

\begin{tabular}{|c|c|c|c|c|c|c|}
\hline & \multirow[t]{2}{*}{ Rhizotomy } & \multicolumn{2}{|l|}{ Collagen IV } & \multicolumn{2}{|l|}{ TGF- $\beta_{1}$} & \multirow[t]{2}{*}{ TGF- $\beta_{1}$ PCR } \\
\hline & & glomeruli & interstitium & glomeruli & interstitium & \\
\hline \multicolumn{7}{|l|}{ Sham } \\
\hline \multirow[t]{2}{*}{ Water } & $-(\mathrm{n}=5)$ & $0.07 \pm 0.05$ & $0.21 \pm 0.12$ & $0.08 \pm 0.03$ & $0.20 \pm 0.05$ & $1.02 \pm 0.37$ \\
\hline & $+(\mathrm{n}=5)$ & $0.07 \pm 0.05$ & $0.24 \pm 0.10$ & $0.08 \pm 0.02$ & $0.14 \pm 0.02$ & $0.80 \pm 0.25$ \\
\hline \multirow[t]{2}{*}{ Quinapril } & $-(\mathrm{n}=5)$ & $0.08 \pm 0.04$ & $0.20 \pm 0.14$ & $0.10 \pm 0.02$ & $0.18 \pm 0.07$ & $1.02 \pm 0.35$ \\
\hline & $+(\mathrm{n}=5)$ & $0.07 \pm 0.04$ & $0.30 \pm 0.10$ & $0.11 \pm 0.03$ & $0.22 \pm 0.05$ & $1.12 \pm 0.37$ \\
\hline \multicolumn{7}{|l|}{ SNX } \\
\hline \multirow[t]{2}{*}{ Water } & $-(\mathrm{n}=7)$ & $0.6 \pm 0.07$ & $0.92 \pm 0.17$ & $0.57 \pm 0.04$ & $0.49 \pm 0.09$ & $3.00 \pm 0.60$ \\
\hline & $+(\mathrm{n}=7)$ & $0.57 \pm 0.07$ & $0.36 \pm 0.10^{c}$ & $0.48 \pm 0.08$ & $0.45 \pm 0.10$ & $1.88 \pm 0.70$ \\
\hline \multirow[t]{2}{*}{ Quinapril } & $-(\mathrm{n}=7)$ & $0.20 \pm 0.08^{\mathrm{a}, \mathrm{b}}$ & $0.73 \pm 0.21^{\mathrm{a}}$ & $0.41 \pm 0.07$ & $0.46 \pm 0.09$ & $1.34 \pm 0.37$ \\
\hline & $+(n=7)$ & $0.25 \pm 0.06^{\mathrm{a}, \mathrm{b}}$ & $0.45 \pm 0.14^{\mathrm{a}}$ & $0.32 \pm 0.08^{\mathrm{a}}$ & $0.42 \pm 0.17$ & $1.04 \pm 0.30^{\mathrm{a}}$ \\
\hline ANOVA & & $\mathrm{p}<0.05$ & $\mathrm{p}<0.05$ & $\mathrm{p}<0.05$ & n.s. & $\mathrm{p}<0.05$ \\
\hline
\end{tabular}

${ }^{\mathrm{a}} \mathrm{p}<0.05$ vs. SNX + no intervention; ${ }^{\mathrm{b}} \mathrm{p}<0.05 \mathrm{vs}$. SNX + water + rhizotomy; ${ }^{\mathrm{c}} \mathrm{p}<0.05 \mathrm{vs}$. SNX + quinapril + rhizotomy. $+=$ Animals with rhizotomy; $-=$ animals with sham rhizotomy.

Table 7. Immunohistochemical analysis of nitro-oxidative markers in the glomeruli (mean score \pm SD) and NOS-3 whole kidney real-time PCR results (mean relative expression level $\pm \mathrm{SD}$ )

\begin{tabular}{llllll}
\hline & Rhizotomy & Nitrotyrosine & NOS-1 & NOS-3 & NOS-3 PCR \\
\hline Sham & & & & & \\
Water & $-(\mathrm{n}=5)$ & $0.14 \pm 0.04$ & $0.58 \pm 0.11$ & $0.73 \pm 0.13$ & $0.88 \pm 0.16$ \\
& $+(\mathrm{n}=5)$ & $0.17 \pm 0.09$ & $0.72 \pm 0.27$ & $0.76 \pm 0.09$ & $0.91 \pm 0.14$ \\
Quinapril & $-(\mathrm{n}=5)$ & $0.15 \pm 0.03$ & $0.79 \pm 0.14$ & $0.77 \pm 0.13$ & $0.76 \pm 0.32$ \\
& $+(\mathrm{n}=5)$ & $0.11 \pm 0.04$ & $0.67 \pm 0.36$ & $0.79 \pm 0.03$ & $0.95 \pm 0.17$ \\
\hline SNX & & & & & \\
Water & $-(\mathrm{n}=7)$ & $0.98 \pm 0.18$ & $1.33 \pm 0.09$ & $0.46 \pm 0.09$ & $1.33 \pm 0.39$ \\
& $+(\mathrm{n}=7)$ & $0.89 \pm 0.11^{\mathrm{b}}$ & $0.84 \pm 0.09$ & $0.47 \pm 0.18^{\mathrm{b}}$ & $0.93 \pm 0.12$ \\
Quinapril & $-(\mathrm{n}=7)$ & $0.66 \pm 0.12$ & $0.72 \pm 0.04$ & $0.63 \pm 0.09$ & $0.98 \pm 0.28$ \\
& $+(\mathrm{n}=7)$ & $0.50 \pm 0.11^{\mathrm{a}}$ & $0.65 \pm 0.15^{\mathrm{a}}$ & $0.80 \pm 0.11^{\mathrm{a}}$ & $1.00 \pm 0.13$ \\
\hline ANOVA & & $\mathrm{p}<0.005$ & $\mathrm{p}<0.005$ & $\mathrm{p}<0.05$ & n.s. \\
\hline
\end{tabular}

${ }^{\mathrm{a}} \mathrm{p}<0.05$ vs. SNX + no intervention; ${ }^{\mathrm{b}} \mathrm{p}<0.05$ vs. SNX + quinapril + rhizotomy. $+=$ Animals with rhizotomy; $-=$ animals with sham rhizotomy. glomeruli, which are known to have higher glomerular capillary pressure [20] and to be more susceptible to injury.

From the large array of available ACE inhibitors we deliberately used quinapril, because this formulation was claimed to achieve the highest tissue concentrations in the kidney, and thus presumably optimal inhibition of local tissue RAAS [21].

Hypertension in chronic renal disease is to a large part due to sympathetic overactivity triggered by afferent sig- nals emanating from the kidney and resetting sympathetic tone by stimulation of hypothalamic centers [22]. Sympathetic overactivity not only elevates blood pressure, but also accelerates progression of renal failure. Renal sympathetic nerves are a critical link between the SNS and long-term arterial pressure control [23]. We decided not to interfere with efferent renal sympathetic nerve activity, since it has been reported that this increases renal resistance [24] and denervation natriuresis [25] potentially causing rebound activation of RAAS. We 

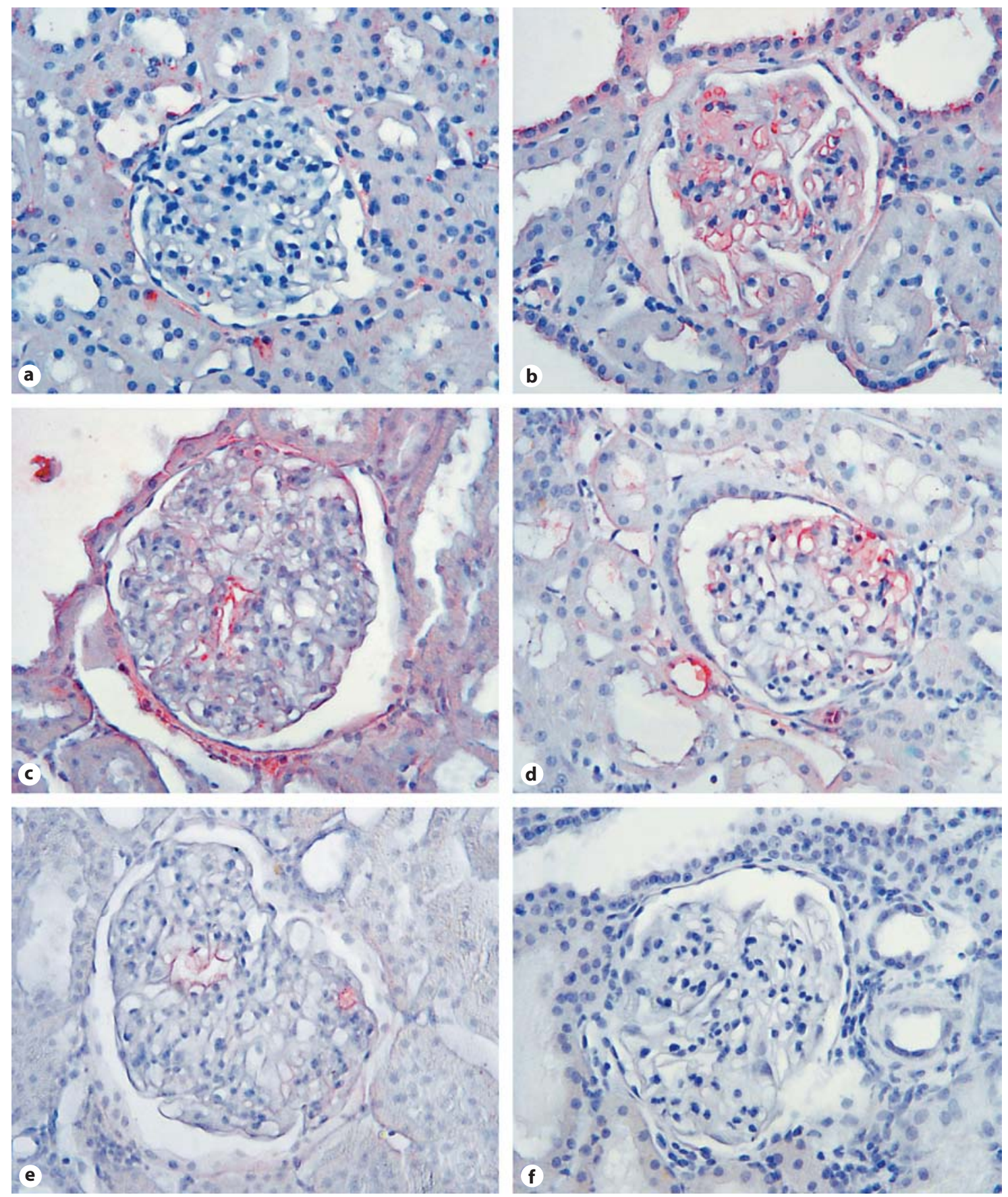

Fig. 4. TGF- $\beta_{1}$ immunohistochemical staining of glomeruli. a Sham-nephrectomized animal. b SNX: water, sham rhizotomy. c SNX: quinapril, sham rhizotomy. d SNX: water, rhizotomy. e SNX: quinapril, rhizotomy. f Negative control. Magnification $\times 400$.

therefore selected the procedure of surgical ablation of sympathetic afferent nerve traffic.

Systolic blood pressure by tail plethysmography and telemetry was lowered, but not normalized, by rhizotomy alone, confirming the results of Campese and Kogosov [6]. Modest further reduction in systolic blood pressure was seen in SNX treated with quinapril plus rhizotomy. The blood pressure differences between groups by telem- 

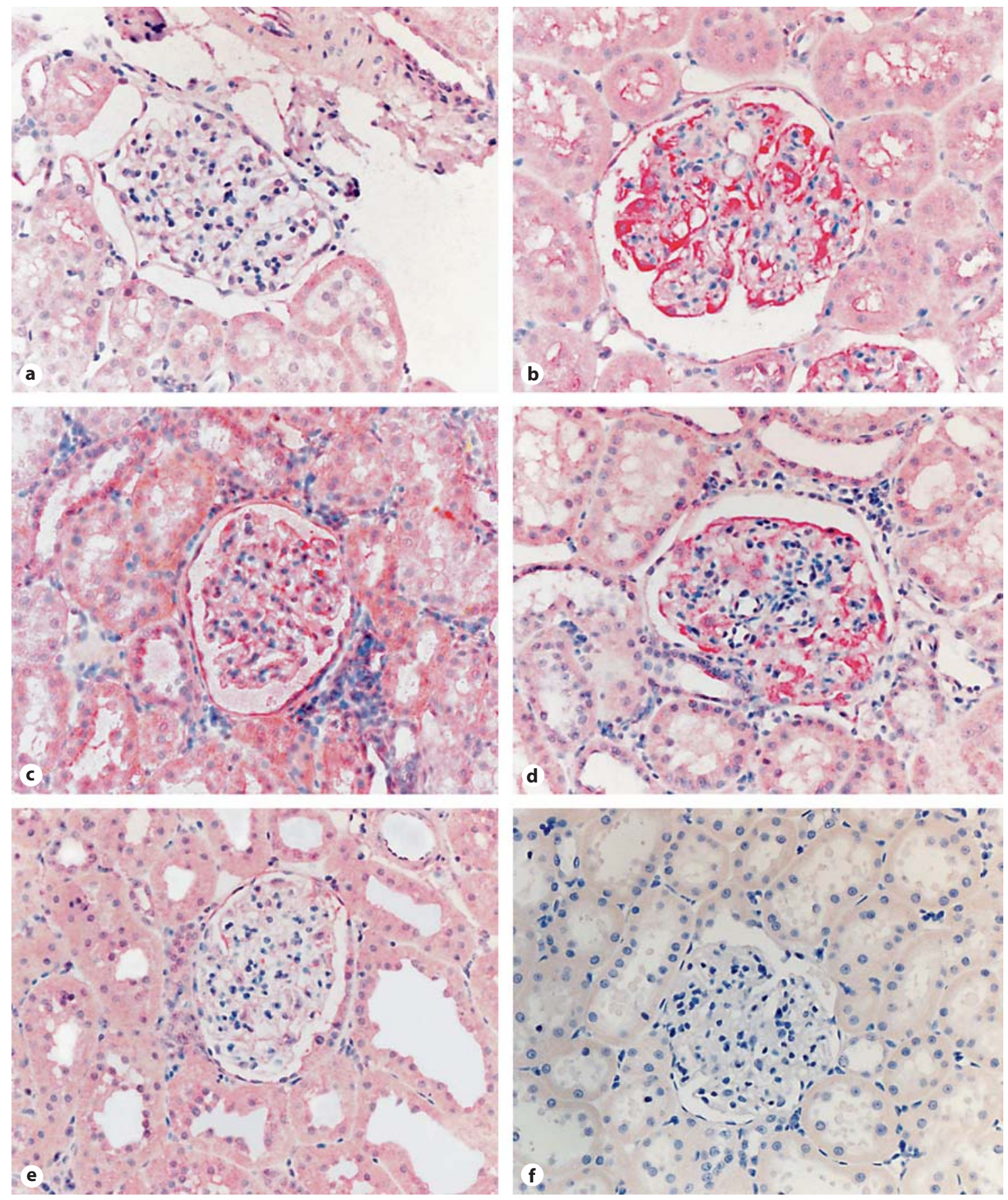

Fig. 5. Nitrotyrosine immunohistochemistry of podocytes. a Sham-nephrectomized animal. b SNX: water, sham rhizotomy. c SNX: quinapril, sham rhizotomy. d SNX: water, rhizotomy. e SNX: quinapril, rhizotomy. f Negative control. Magnification $\times 400$.

etry, the only reliable method, were minimal. It is unlikely that such small blood pressure differences account, for instance, for the marked differences of nitro-oxidative stress in podocytes. General sympathetic inhibition has been shown to be nephroprotective: in SNX rats moxonidine or metoprolol reduced glomerular damage. This effect was independent of blood pressure $[8,9]$. In patients with chronic kidney disease, inhibition of the SNS 
by moxonidine on top of RAAS inhibition proved to be beneficial $[26,27]$. Finally, in diabetic patients reduction of sympathetic activity by moxonidine lowered albumin excretion independently of blood pressure [28].

Paradoxically, but in line with our previous experiments quinapril-treated animals consistently had higher serum creatinine and urea concentrations, possibly because of lower glomerular capillary pressures and filtration rates secondary to diminished efferent resistance $[8$, 29]. The serum creatinine concentration was significantly $(\mathrm{p}<0.05)$ lower in animals with rhizotomy, either alone or in combination with quinapril, possibly pointing to an independent beneficial effect of reduced sympathetic activation on intrarenal hemodynamics. Sympathetic signals are a potent stimulus for renin transcription and secretion [30,31], but in animals with RAS blockade it is unlikely that the effect of abrogation of sympathetic activity was mediated by changes in renin secretion, since the high dose of the ACE inhibitor had already caused major inhibition of the juxtaglomerular RAS. In animals with rhizotomy, but not on quinapril, the length density per glomerulus was largely preserved. It had previously been shown that in SNX rhizotomy normalized reduced capillary length density in glomeruli [9] and the same had previously been noted in the heart [19]. Rhizotomy failed to affect glomerular capillary length density in sham-operated animals, but it apparently modulated the effect of nephron loss on glomerular capillarogenesis. Interestingly, changes in capillary length density were not accompanied by commensurate changes in endothelial cell number and endothelial cell volume: the endothelial cell number was influenced by quinapril, but not by rhizotomy. Angiotensin II (ANG II) is known to be an agonist for mesangial cell proliferation; it is therefore not surprising that in quinapril-treated SNX the mesangial cell number was lower. It was not affected by rhizotomy despite the known role of catecholamines in mesangial cell proliferation [32]. The increase in podocyte volume was partially reversed by quinapril. This observation is consistent with recent observations that podocytes have a potent local RAS, can produce ANG II and express AT1 receptors [33].

Certainly the best-established profibrotic cytokine involved in renal scarring is TGF- $\beta_{1}$. Glomerular TGF- $\beta_{1}$ expression was significantly lower in SNX animals treated by combination therapy. It is true that ANG II increases the expression of TGF- $\beta_{1}$ and this is thought to mediate the profibrotic action of ANG II $[34,35]$, but sympathetic activity also seems to play a role: moxonidin decreased glomerular TGF- $\beta_{1}$ mRNA in SNX rats [8].
Nitrotyrosine is a stable metabolite of oxidative modified nitrogen monoxide and a marker of nitro-oxidative stress. A 10-fold elevation of nitrotyrosine staining despite reduced expression of nitrogen monoxide synthases (NOS-3: eNOS) suggests massive oxidative stress in untreated SNX animals. Double intervention preserved both NOS-3 expression, and normalized nitrotyrosine staining to sham control levels.

We conclude that in SNX rats concomitant abrogation of sympathetic activity strikingly augments the effect of ACE inhibition and has presumably blood pressure-independent beneficial effects. This observation provides a rationale for combination treatment.

\section{Acknowledgements}

Support was provided to P. Hamar from the University Scholar Exchange Program between the Semmelweis University and the University of Heidelberg, the German Academic Exchange (DAAD; Wiedereinladung), OMFB-Tet CHN-10/03, Data Sciences International [Telemetry Acquisition Grant (TAG)], and the Hungarian Research Fund: OTKA F034498, T049022 and ETT 432/2003, DAAD (Intergovernmental Scientist Exchange Program OMFB No. 6), Kröner-Fresenius Stiftung, and Marie Curie Fellowship (HPMF-CT-2001-01501). This research has been supported by DFG (KFG 106, TP6) and the Faculty of Medicine, University of Heidelberg. The skillful technical assistance of H. Ziebart, P. Rieger, Z. Antoni and M. Weckbach is gratefully acknowledged. 


\section{References}

1 Rennke HG, Klein PS: Pathogenesis and significance of nonprimary focal and segmental glomerulosclerosis. Am J Kidney Dis 1989;13:443-456.

2 Remuzzi G, Bertani T: Pathophysiology of progressive nephropathies. N Engl J Med 1998;339:1448-1456.

3 Lewis EJ, Hunsicker LG, Clarke WR, et al: Renoprotective effect of the angiotensin-receptor antagonist irbesartan in patients with nephropathy due to type 2 diabetes. $\mathrm{N}$ Engl J Med 2001;345:851-860.

4 Lewis EJ, Hunsicker LG, Bain RP, Rohde RD: The effect of angiotensin-converting-enzyme inhibition on diabetic nephropathy. The Collaborative Study Group. N Engl J Med 1993;329:1456-1462.

5 Brenner BM, Cooper ME, de Zeeuw D, et al: Effects of losartan on renal and cardiovascular outcomes in patients with type 2 diabetes and nephropathy. N Engl J Med 2001;345: 861-869.

6 Campese VM, Kogosov E: Renal afferent denervation prevents hypertension in rats with chronic renal failure. Hypertension 1995; 25 : 878-882.

7 Ye S, Zhong H, Yanamadala V, Campese VM: Renal injury caused by intrarenal injection of phenol increases afferent and efferent renal sympathetic nerve activity. Am J Hypertens 2002;15:717-724.

8 Amann K, Rump LC, Simonaviciene A, et al: Effects of low dose sympathetic inhibition on glomerulosclerosis and albuminuria in subtotally nephrectomized rats. J Am Soc Nephrol 2000;11:1469-1478.

9 Amann K, Koch A, Hofstetter J, et al: Glomerulosclerosis and progression: effect of subantihypertensive doses of alpha and beta blockers. Kidney Int 2001;60:1309-1323.

10 Rump LC, Oberhauser V: Chronic renal failure - taming the sympathetic nervous system! New approach to delaying progression. MMW Fortschr Med 1999;141:39-41.

11 Hostetter TH: The next treatments of chronic kidney disease: if we find them, can we test them? J Am Soc Nephrol 2002;13:30243026.

12 Benigni A, Zoja C, Corna D, et al: Add-on anti-TGF-beta antibody to ACE inhibitor arrests progressive diabetic nephropathy in the rat. J Am Soc Nephrol 2003;14:1816-1824.
13 Schwarz U, Amann K, Orth SR, et al: Effect of $1,25(\mathrm{OH})_{2}$ vitamin $\mathrm{D}_{3}$ on glomerulosclerosis in subtotally nephrectomized rats. Kidney Int 1998;53:1696-1705.

14 Bunag RD: Validation in awake rats of a tailcuff method for measuring systolic pressure. J Appl Physiol 1973;34:279-282.

15 Magnotti RA Jr, Stephens GW, Rogers RK Pesce AJ: Microplate measurement of urinary albumin and creatinine. Clin Chem 1989;35:1371-1375.

16 el Nahas AM, Zoob SN, Evans DJ, Rees AJ: Chronic renal failure after nephrotoxic nephritis in rats: contributions to progression. Kidney Int 1987;32:173-180.

17 Kang DH, Hughes J, Mazzali M, et al: Impaired angiogenesis in the remnant kidney model. II. Vascular endothelial growth factor administration reduces renal fibrosis and stabilizes renal function. J Am Soc Nephrol 2001;12:1448-1457.

18 Amann K, Nichols C, Tornig J, et al: Effect of ramipril, nifedipine, and moxonidine on glomerular morphology and podocyte structure in experimental renal failure. Nephrol Dial Transplant 1996;11:1003-1011.

19 Torry RJ, Connell PM, O'Brien DM, et al Sympathectomy stimulates capillary but not precapillary growth in hypertrophic hearts. Am J Physiol 1991;260:H1515-H1521.

20 Skov K, Nyengaard JR, Patwardan A, Mulvany MJ: Large juxtamedullary glomeruli and afferent arterioles in healthy primates. Kidney Int 1999;55:1462-1469.

21 Culy CR, Jarvis B: Quinapril: a further update of its pharmacology and therapeutic use in cardiovascular disorders. Drugs 2002;62: 339-385.

22 Orth SR, Amann K, Strojek K, Ritz E: Sympathetic overactivity and arterial hypertension in renal failure. Nephrol Dial Transplant 2001;16(suppl 1):67-69.

23 Lohmeier TE: The sympathetic nervous system and long-term blood pressure regulation. Am J Hypertens 2001;14:147S-154S.

24 LeNoble LM, Lappe RW, Brody MJ, et al: Selective efferent chemical sympathectomy of rat kidneys. Am J Physiol 1985;249:R496R501.
25 Szenasi G, Bencsath P, Szalay L, Takacs L: Fasting induces denervation natriuresis in the conscious rat. Am J Physiol 1985;249: F753-F758.

26 Neumann J, Ligtenberg G, Oey L, et al: Moxonidine normalizes sympathetic hyperactivity in patients with eprosartan-treated chronic renal failure. J Am Soc Nephrol 2004; 15:2902-2907.

27 Vonend O, Marsalek P, Russ H, et al: Moxonidine treatment of hypertensive patients with advanced renal failure. J Hypertens 2003;21:1709-1717.

28 Strojek K, Grzeszczak W, Gorska J, et al: Lowering of microalbuminuria in diabetic patients by a sympathicoplegic agent: novel approach to prevent progression of diabetic nephropathy? J Am Soc Nephrol 2001;12: 602-605.

29 Rosenberg ME, Hostetter TH: Comparative effects of antihypertensives on proteinuria: angiotensin-converting enzyme inhibitor versus alpha 1-antagonist. Am J Kidney Dis 1991;18:472-482.

30 DiBona GF: Neural control of the kidney: past, present, and future. Hypertension 2003:41:621-624

31 DiBona GF: The sympathetic nervous system and hypertension: recent developments. Hypertension 2004;43:147-150.

32 Boivin V, Jahns R, Gambaryan S, et al: Immunofluorescent imaging of beta 1 - and beta 2 -adrenergic receptors in rat kidney. Kidney Int 2001;59:515-531.

33 Durvasula RV, Petermann AT, Hiromura K, et al: Activation of a local tissue angiotensin system in podocytes by mechanical strain. Kidney Int 2004;65:30-39.

34 Wolf G, Mueller E, Stahl RA, Ziyadeh FN: Angiotensin II-induced hypertrophy of cultured murine proximal tubular cells is mediated by endogenous transforming growth factor-beta. J Clin Invest 1993;92:13661372.

35 Kagami S, Border WA, Miller DE, Noble NA: Angiotensin II stimulates extracellular matrix protein synthesis through induction of transforming growth factor-beta expression in rat glomerular mesangial cells. J Clin Invest 1994;93:2431-2437. 